\title{
Control of death receptor ligand activity by posttranslational modifications
}

\author{
R. Weinlich - T. Brunner - G. P. Amarante-Mendes
}

\begin{abstract}
The death receptor ligands are involved in many physiological and pathological processes involving triggering of apoptosis, inflammation, proliferation, and activation. The expression of these molecules is reported to be tightly regulated at the transcriptional level. However, over the last few years, an increasing number of data demonstrated that the control of transcription is only one of the mechanisms that manage the expression of the death receptor ligands. Thus, this review is focused on posttranslational regulation of the three main members of this family, namely FasL, TNF- $\alpha$, and TRAIL. We discuss here the importance of distribution, storage, and degranulation of these molecules, as well as their shedding by proteases on the control of death receptor ligands expression and activity.
\end{abstract}

Keywords FasL . TNF - TRAIL - Rafts - Lysosomes · Degranulation · ADAM - Metalloprotease $\cdot$ Shedding

R. Weinlich - G. P. Amarante-Mendes

Departamento de Imunologia, Instituto de Ciências Biomédicas, Universidade de São Paulo, São Paulo, Brazil

R. Weinlich - G. P. Amarante-Mendes

Instituto de Investigação em Imunologia,

Instituto Nacional de Ciência e Tecnologia (INCT),

São Paulo, Brazil

T. Brunner

Division of Immunopathology, Institute of Pathology,

University of Bern, Bern, Switzerland

Present Address:

$\mathrm{R}$. Weinlich (囚)

Department of Immunology, St. Jude Children's Research

Hospital, Mail Stop 351. 262 Danny Thomas Place,

Memphis, TN 38105, USA

e-mail: Ricardo.Weinlich@stjude.org

\section{Introduction}

The family of death receptors (DRs) belongs to the larger superfamily of tumor necrosis factor (TNF) receptors. Members of this subfamily, such as Fas (CD95/APO-1), TNF-R1, TNF-R2, TRAMP (DR3), TRAIL-R1 (DR4), TRAIL-R2 (DR5), DR6, EDAR, and p75NTR, contain an exclusive a 80 amino acid-long domain called "death domain", that is essential for apoptosis induction [1, 2]. They are activated by their cognate ligands, which belong to the TNF- $\alpha$ protein family and are usually called "death receptor ligands" $[3,4]$. These molecules are comprised of a C-terminal extracellular portion (which interacts with DRs), a transmembrane domain, and an $\mathrm{N}$-terminal domain $[5,6]$. An exception is lymphotoxin- $\alpha(\mathrm{LT} \alpha)$, which is produced as a soluble protein. The most studied and welldescribed members of the death receptor ligands family are the FasL (CD95L), tumor necrosis factor alpha (TNF- $\alpha$ ) and the TNF-related apoptosis-inducing ligand (TRAIL).

FasL is the prototypical death receptor ligand. It is mostly expressed in the hematopoietic compartment, including dendritic cells and $\mathrm{NK}, \mathrm{B}$, and T lymphocytes but can also be found in immune privileged sites, such as retina, testis, and ovary as well as in chronically inflamed tissues [7, 8]. FasL is a well-known apoptosis inducer and therefore it is involved in many physiological and pathological situations that result in cell death. FasL expression on effector cells can trigger death of target cells. However, when expressed in $\mathrm{T}$ cells, it can also induce a suicide process called activation-induced cell death (AICD) [9], involved in the deletion of autoreactive or chronically stimulated $\mathrm{T}$ cells and thereby contributing to the maintenance of the homeostasis of the immune system [10]. In non-hematopoietic tissues, FasL expression is important for the protection of immune privileged sites from damage 
inflicted by infiltrating immune/inflammatory cells [11]. In addition to its proapoptotic role, FasL has also been shown to induce $\mathrm{T}$ cell activation and proliferation [12].

TNF- $\alpha$ is better known for its pro-inflammatory activity. It is involved in a myriad of physiological and pathological processes, including inflammation, reproduction, metabolism, and immune responses. TNF- $\alpha$ not only induces cell death but also proliferation, differentiation, and activation of immune and non-immune cells [13]. TNF- $\alpha$ expression is tightly regulated and occurs mainly in hematopoietic cells, such as macrophages, monocytes, neutrophils, and lymphocytes, although it can also be found in some nonhematopoietic cells, like the microglia, fibroblasts, and muscle cells [13]. In regard to its pro-apoptotic function, TNF- $\alpha$ is known to be the major mediator of macrophageinduced cytotoxicity but is also important for $\mathrm{T}$ cellmediated killing [14] .

In contrast to FasL and TNF- $\alpha$, TRAIL is widely and constitutively expressed, both in non-hematopoietic tissues, like colon, placenta, and small intestine, and in hematopoietic tissues including spleen, thymus, and lymph nodes [15]. In some cell types, especially immune cells, TRAIL is upregulated in response to diverse stimuli, such as TCR stimulation and IFN type I for T cells, LPS for monocytes and macrophages, and IFN type I, IL-12, and IL-15 for NKs [16-19]. Although TRAIL is reported to have different functions, including inhibition of proliferation [20], regulation of hematopoiesis [21], and killing of virusinfected cells [22], the most studied role of this protein is the induction of apoptosis in tumors. Differently from TNF- $\alpha$ and FasL, TRAIL specifically induces apoptosis in a vast number of tumors without killing non-transformed cells [23-26]. Furthermore, it synergizes with radiotherapy, chemotherapeutic drugs, and other death receptor ligands to promote tumor cell death [27-30]. However, TRAIL may induce liver damage under some stress and/or inflammatory conditions $[31,32]$.

Although primarily produced as transmembrane proteins, the death receptor ligands can be released by proteolytic cleavage, which may alter their biological activities. Whereas transmembrane ligands in general possess potent pro-apoptotic activities, soluble proteins may maintain apoptosis activities, acquire antagonistic properties, or become pro-inflammatory cytokines $[3,6,33,34]$. Thus, given the important biological functions of death receptor ligands, it is not surprising that their expression and availability are tightly regulated at both the transcriptional and posttranslational levels. Besides the fundamental role of death receptor ligands modulation at the transcriptional level, there is an increasing body of evidence pointing towards a critical role of posttranscriptional mechanisms in the regulation of death receptor ligands' availability and activity. We will focus on posttranslational control of FasL,
TNF- $\alpha$, and TRAIL, and discuss the role of sorting, storage, and distribution of these proteins in the membranes, as well as their shedding by proteolysis, on the regulation of death receptor ligand activity. For transcriptional regulation of death receptors ligands, please refer to [35-38].

\section{Sorting and storage}

In some cell types, de novo synthesized FasL is directly targeted to the plasma membrane, as is the case in the retina, placenta, testis, and tumor cells such as colon and breast cancer cells. Direct translocation of de novo synthesized FasL to the plasma membrane is normally associated with immune privileged sites or malignancies [39-43]. In other cells, mostly from the haematopoietic lineages, like cytotoxic $\mathrm{T}$ cells and NK cells, FasL can either be directly transported to the plasma membrane or stored in granule-like structure, normally described as secretory lysosomes [44-46]. Interestingly, intracellular storage of FasL is usually observed in cell types with inducible FasL expression, e.g., T cells and NK cells [45, $47,48]$. Stimulation of these cells not only induces de novo synthesis and direct transportation of FasL to the cell surface but also promotes degranulation of preformed FasL, which further contributes to engagement of the Fas receptor on the target cells and induction of target cell killing $[45,49]$. Thus, storage of FasL in secretory lysosomes adds an additional level of control of this dangerous death-inducing ligand.

Secretory lysosomes are acidic double-membrane organelles similar to conventional lysosomes in the sense that they have all the protease machinery requested for degradative processes $[50,51]$; however, they also function as storage compartments for secreted proteins, including histamine, perforins, granzymes, and FasL [52-54]. Upon appropriated stimuli, like the recognition of a target cell, the vesicles are directed to the site of interaction where they fuse with the plasma membrane, exposing previously stored membrane-attached proteins and also releasing their soluble content [55].

Although initial data indicated that storage and degranulation of FasL is similar to the general mechanism described for other lysosomal proteins, like granzymes, currently it is accepted that FasL is sorted and released by different mechanisms. In 1999, Bossi and Griffiths showed that FasL usually co-localizes with markers of secretory lysosomes-CD63, perforin, and granzyme - in CTLs and NKs as well as in activated CD4+ T cells [45]. Additional support for the co-localization of FasL and perforin was provided by Kojima et al. [56], who showed that FasL stained at the periphery of the same granules whose cores stained for perforin. However, later work by Kassahn et al. 
showed that ectopically-expressed FasL in Jurkat cells was rarely found in the same granules as CD63 and CD107a, both markers of secretory lysosomes [57], and the same pattern was also described for a murine CTL clone [49]. Indeed, a recent paper from Schmidt et al. [58] revealed that, upon extensive fractioning of the cytolytic granules, FasL was enriched in a different fraction than perforin, granzymes, and other conventional secretory lysosomes markers. They speculated that distinct secretory lysosomes subtypes may form from an initial multivesicular complex, resulting in two independent compartments. The characterization of specific markers for these lysosome subsets might shed light on these contradictory data concerning FasL subcellular localization.

In accordance with the distinct FasL storage site, FasL is transported to secretory lysosomes by an unconventional pathway, which is dependent on the FasL proline-rich domain (PRD) and independent of the well-established di-leucine/tyrosine-based domains, which are lacking in the FasL cytoplasmic tail $[44,59,60]$. In the absence of the PRD domain, FasL travels by default to the plasma membrane indicating that this domain is critical for sorting FasL to the secretory lysomes. While FasL devoid of this PRD goes directly to the cell surface, its integration into distinct sites of the plasma membrane (like membrane rafts) is also disturbed (further discussed below) [44, 61].

Molecular modeling of FasL PRD predicted that this domain could interact with proteins that contain Src-homology 3 (SH3) domains or WW motifs [44], and further studies showed that, at least in vitro, FasL PRD can promiscuously interact with a large list of $\mathrm{SH} 3$ and/or WW-containing proteins [62-64]. These include the Fyn, Lyn, and Fgr kinases, the adaptor proteins Nck, Grb2, and PSTPIP, and the Pombe Cdc15 homology (PHC) proteins PACSIN1-3, FPB17, CIP4, and CD2BP1 [46, 64-67]. Thus, overexpression of $\mathrm{PHC}$ proteins in nonhematopoietic cells promotes, at least partially, the sorting of FasL to the secretory lysosomes instead of to the plasma membrane [46]. The same was found for PSTPIP, which also caused a reduction of FasL-mediated cytotoxicity due to a reduced FasL surface expression [68]. Interestingly, the internalization of FasL to the secretory lysosomes is dependent on SH3-containing Src kinases phosphorilation of FasL PRD and also the mono-ubiquitylation of this domain [69]. Finally, FasL PRD also plays a role during degranulation. Thornhill et al. investigated the participation of the adaptor protein Grb2 and found that it is important to sort FasL to the plasma membrane through its connection to adaptin- $\beta$, a well-established molecule involved in protein trafficking. In cells with reduced levels of GrB2, FasL accumulated in intracellular vesicles [70]. Finally, Nck may be involved in the degranulation of vesicle-stored FasL into the immunological synapse of TCR-stimulated T cells, by a mechanism dependent on actin cytoskeleton and on WASP/WIP proteins [67].

As TNF- $\alpha$ and TRAIL have a much smaller cytoplasmic tail and do not present the PRD domain [63], it is believed that they are not trafficked to secretory lysosomes the same way as FasL. TNF- $\alpha$ is thought to be targeted to the secretory lysosomes after a transient exposure in the plasma membrane followed by re-endocytosis [71]. In rodents, N-linked glycosylation of mannose-6-phosphate residues is required for proper sorting [72], while in humans, the TNF- $\alpha$ cytoplasmic tail is dispensable [71]. In fact, the accumulation of TNF- $\alpha$ is practically restricted to mast cells $[73,74]$, while in the other cell types, TNF- $\alpha$ is synthesized as a $26-\mathrm{kDa}$ transmembrane protein, and later on proteolytically processed on the plasma membrane to a 17-kDa soluble form [75]. Although some papers have shown that TRAIL accumulates in diverse granular structures, like secretory lysosomes, the mechanism of TRAIL trafficking is still unknown [76-80]. Interestingly, de novo synthesized TRAIL molecules in neutrophils are stored in slightly different vesicles, indicating that more than one mechanism is involved in TRAIL sorting $[76,77]$.

\section{Distribution in the membrane}

Membrane rafts are plasma membrane compartments enriched for sphingolipids and cholesterol [81]. They are less fluid and more ordered than the phospholipid-rich portions of the plasma membrane, conferring them great lateral mobility without losing their integrity [82]. They usually contain various receptors and molecules involved in several signaling pathways and, as they can aggregate in larger structures, they are involved in controlling the intensity and efficiency of the response to diverse cellular stimuli, including TCR, BCR, and FceR engagement [83]. Thus, membrane rafts often represent signaling platforms. They have also been reported to be involved in regulating death-receptor-mediated induction of apoptosis $[84,85]$.

Recently, two independent groups demonstrated that FasL recruitment to the membrane rafts is an important posttranscriptional event, which strongly enhances the killing activity of this molecule $[61,86]$. Indeed, the disruption of membrane rafts in $\mathrm{T}$ cells by various means, e.g., cholesterol depletion, cholesterol sequestration, or inhibition of cholesterol synthesis, strongly inhibits FasLinduced target cell killing [61]. Further support for these results is provided by two other publications, which show that enforced expression of FasL in HeLa cells resulted in its translocation to the rafts [87], and in Jurkat cells, FasL was recruited to the membrane microdomains upon aplidin-mediated chemotherapy [88]. It is also important to point out that high-stability supramolecular Fas-FasL 
clusters are formed in the contact site between effector and target cells, which may be partially mediated by recruit ment of FasL into the membrane rafts [87].

The mechanism for enhanced FasL killing activity by clustering in membrane rafts may be explained by the fact that the proper formation of death-inducing signaling complex (DISC) during Fas triggering is dependent on (at least) two adjacent FasL molecules [89] and that, upon interaction with Fas, FasL may become aggregated within the membrane rafts [86]. In fact, different reports have shown that raft localization is important for activation of downstream signaling events and apoptosis induction [90-92]. It is thus feasible to speculate that, in the absence of proper clustering of FasL, killing of the target cell might be limited. In contrast, the non-polarized distribution of FasL throughout the plasma membrane could also result in uncontrolled bystander killing of unrelated neighboring cells. Thus, accumulation and aggregation of FasL in membrane rafts of cytotoxic lymphocytes may assure specific and efficient killing of the target cells by focusing the signal towards them and by promoting, in target cells, the clustering of Fas receptor in membrane rafts.

Substantial data relating to TNF- $\alpha$ and TRAIL distribution in the different plasma membrane microdomains is still lacking, but it is interesting to note that the recruitment of the TNF-R1 into the membrane rafts results in the opposite effect than Fas receptor clustering. Rather than enhancing apoptosis induction, membrane raft-clustered TNF-R1 preferentially induces $N F-\kappa B$ activation, resulting in enhanced pro-inflammatory and pro-survival responses [84, 91, 93]. Also, TRAIL-R1 and -R2 can be recruited to the membrane rafts, enhancing the susceptibility to apoptosis induction $[88,94]$.

Different mechanisms for the recruitment of molecules into the membrane rafts have been described, including phosphorylation, myristoylation, palmitoylation, and double acetylation [94-97], as well as the interaction with trafficking proteins or proteins anchored in the rafts [70]. In the case of FasL, the domain responsible for raft localization was mapped as being the proline rich domain (PRD). Deletion of this domain strongly reduced the recruitment of FasL into the rafts and, as a consequence, diminished FasLdependent killing of target cells. In contrast, the deletion of a casein kinase II target site, named SxxS motif, did not affect raft recruitment [61]. As described in the previous section, the PRD domain is also involved in the trafficking of FasL to secretory lysosomes and to the plasma membrane, indicating that this domain has a broad role on FasL transportation. The PRD domain enables interactions with proteins containing SH3 or WW motifs. Among them Fyn and Lck seemed to be the best candidates to modulate the trafficking of FasL to the membrane rafts, since they physically interact with FasL and reside inside this structure $[64,66]$. However, to date, none of these molecules has been convincingly shown to be involved in FasL recruitment to membrane rafts. On the contrary, Nachbur and colleagues did not find more FasL in membrane rafts in 293 T cells ectopically expressing Lck and Fyn [61].

Taking into the consideration that: (1) depending on cell type, FasL can be mostly stored in secretory lysosomes, distributed throughout the membrane or concentrated in membrane rafts, (2) PRD domain seems to be involved in all trafficking events, and (3) different maturation stages or different stimuli can alter FasL distribution, we speculate that different sets of PRD-interacting proteins may control FasL storage and distribution, and that their expression and availability will affect the final result. Therefore, further studies, focusing on different moments in the differentiation and/or maturation of a FasL-expressing cell as well as different activating signals, are necessary to unravel the underlying mechanisms that govern intracellular storage and surface expression of FasL.

\section{Shedding by proteolytic activity}

Another critical aspect about the regulation of death receptor ligand activity is the conversion of the transmembrane molecule into a soluble ligand by a proteolytic process called shedding. Membrane FasL (mFasL) is considered to be the primarily pro-apoptotic version of FasL while secreted FasL (sFasL) has either no activity or is rather anti-apoptotic $[6,34,98]$. Still, some controversy remains, as sFasL is also described as an inducer of cell death [99-101]. Recently, a study by O'Reilly et al. [102] shone new light on this matter. They generate gene-targeted mice that selectively lack either secreted or transmembrane FasL and demonstrated that, while the former is apparently normal and its cells exhibit normal FasL-mediated cytotoxicity activity, the latter develops lymphadenopathy and autoimmunity, similar to the FasL-deficient gld mice. Moreover, the inhibition of the proteases involved in FasL shedding enhanced CD4 + T cell-mediated cytotoxicity [103], and the expression of a non-cleavable form of FasL in ovarian and cervical carcinoma cells significantly decreased cell survival [104].

Although the first form of $\mathrm{TNF}_{-} \alpha$ discovered was the soluble cytokine, subsequent studies identified the 26-kDa transmembrane form of TNF- $\alpha$ as one of the cytotoxic molecules used by activated $T$ cells and macrophages to kill target cells $[14,105]$. In fact, similarly to FasL, TNF- $\alpha$ is produced as a transmembrane molecule. Membrane bound TNF $-\alpha$ is then converted to its soluble form by ADAM17 (TACE, TNF-alpha converting enzyme), a member of the ADAM (a disintegrin and metalloprotease) family of metalloproteases. Using a non-cleavable transmembrane, TNF- $\alpha$, Perez et al. [106] showed that processing of TNF- $\alpha$ 
is not required to the pro-apoptotic effect of this molecule and that these cells could kill virus-infected target cells by cell-cell contact. Also, transplanted T cells that express only the noncleavable TNF- $\alpha$ presented a decreased graftversus-host disease without impairing its anti-tumor activity [107]. However, only sTNF- $\alpha$ sensitizes $T$ cells for enhanced AICD [108].

Shedding of death receptor ligands is not only important to regulate their pro-apoptotic functions but it also modulates the nonapoptogenic functions of these molecules. STNF- $\alpha$ is a pro-inflammatory cytokine involved in almost all immune responses and also has a critical role in a great variety of inflammatory and/or auto-immune diseases [109]. For example, mTNF- $\alpha$ transgenic mice are protected from LPS-induced death [110] similarly to the animals treated with an inhibitor of $\mathrm{TNF}_{-} \alpha$ sheddase [111], highlighting the importance of a tight control of STNF- $\alpha$ generation. sFasL also has a pro-inflammatory and tumorigenic effect, as depicted by mice expressing only the secreted form of FasL, which develop SLE-like syndromes and histiocytic sarcomas [102].

To date, two members of the ADAM family of metalloproteases were described as being involved in shedding of the death receptor ligands, namely ADAM17 and ADAM10. ADAM17 and ADAM10 share the highest amino-acid identity in comparison to the other ADAMs, and both possess an extracellular zinc-dependent metalloprotease catalytic domain, which is responsible for the shedding activity $[112,113]$.

ADAM17 was implicated for the first time as the main TNF- $\alpha$ sheddase in 1997 in a study that showed that mice with non-functional ADAM17 lacks $90 \%$ of its ability to process precursor $\mathrm{TNF}_{-} \alpha$ [112]. Since then, its role has been confirmed by different groups, but it is still a matter of debate whether ADAM17 is the sole TNF- $\alpha$-processing ADAM [113-115]. Antisense-mediated reduction of ADAM10 expression in THP-1 cells did not alter the quantity of secreted STNF- $\alpha$ [116], and ADAM10 overexpression in MEFs and CHO cells did not enhance TNF- $\alpha$ shedding [115]. On the other hand, human and bovine ADAM10 can cleave recombinant TNF- $\alpha$ [117, 118], and ADAM10 is the main TNF- $\alpha$ sheddase in ADAM17-deficient fibroblasts [119]. Recently, Le Gall et al. have shown that ADAM10 can, over time, compensate for ADAM17 activity in cells chronically treated with ADAM17-specific inhibitors. They propose that the accumulation of some but not all ADAM17 substrates could result in their leakage to compartments where ADAM10 is more active [120], and in this case, ADAM10 could act as a sheddase for these molecules. Taken together, these observations may suggest that ADAM10-dependent TNF- $\alpha$ cleavage depends on cell type and TNF- $\alpha$-inducing stimuli, and also on the subcellular localization/storage of ADAM10 and TNF- $\alpha$.
On the other hand, FasL shedding is totally dependent on ADAM10. Incubation of FasL with recombinant ADAM10 but not with ADAM17 resulted in FasL proteolysis and ADAM10 $0^{-1-}$ but not ADAM17 $7^{-1-}$ MEFs being completely deficient in the generation of soluble FasL [103]. Furthermore, CD4 $+\mathrm{T}$ cells treated with ADAM10 inhibitors enhanced membrane FasL expression, increasing FasL-mediated cytotoxicity and AICD [103]. ADAM10deficient mice die early during embryogenesis, probably due to the lack of the Notch signaling pathway [121]; thus, the relevance of ADAM10-mediated FasL shedding in vivo has yet to be determined.

In addition to the ADAMs, some other metalloproteases are also involved in FasL and TNF- $\alpha$ shedding, as is the case for MMP7 (matrilysin) [122, 123] and MMP3 (stromelysin-1) [124]. However, this activity seems to be accessory to ADAM-mediated FasL and TNF- $\alpha$ shedding since ADAM "loss-of-function" promotes a complete blocking of FasL/TNF- $\alpha$ cleavage while metalloprotease inhibitors normally result in a smaller effect on death receptor ligand shedding [103, 115, 124].

The modulation of the metalloprotease activity involved in TNF- $\alpha$ and FasL shedding is still not completely understood, but it seems that they are induced by addition of phorbol esters and calcium influx $[113,125]$. A family of tissue inhibitors of metalloproteinases (TIMPs), which comprises four different members TIMP-1, $-2,-3$, and -4 , seems to be the mainly endogenous inhibitors of MMPs and ADAM metalloprotease activity [126]. TIMP-3 is reported to be the major inhibitor of TNF- $\alpha$ processing by ADAM17 [127]. While rADAM17 is blocked by TIMP-3, neither TIMP-1 and TIMP-2 showed any effect on its activity. Although the N-terminal domain of TIMP-4 has a strong ability to inhibit TNF- $\alpha$ processing, the full-length protein presents negligible activity in inhibiting ADAM17 [128]. TIMP-1 and TIMP-3 are capable of inhibiting ADAM10 activity, although, to date, nobody has formally demonstrated that TIMP-1 and TIMP-3 block ADAM10mediated FasL shedding.

In agreement with its ability to impair ADAM10 and ADAM17 activities in the majority of in vitro models, TIMP-3 induces apoptosis or renders the cells more susceptible to FasL/TNF- $\alpha$ /TRAIL-induced death [129-131]. This was not observed upon overexpression of TIMP-1, which is normally described as an anti-apoptotic molecule [132]. Its pro-survival effect is independent of the TIMP-1mediated MMP/ADAM inhibition [133, 134] and further studies focusing on FasL-induced cell death may clarify whether TIMP-1 has a pro-apoptotic role by its ability to inhibit ADAM10-mediated FasL shedding.

To date, little is known about TRAIL shedding. Mariani and Krammer showed that metalloprotease inhibitors did not enhance surface TRAIL expression in any cell type 


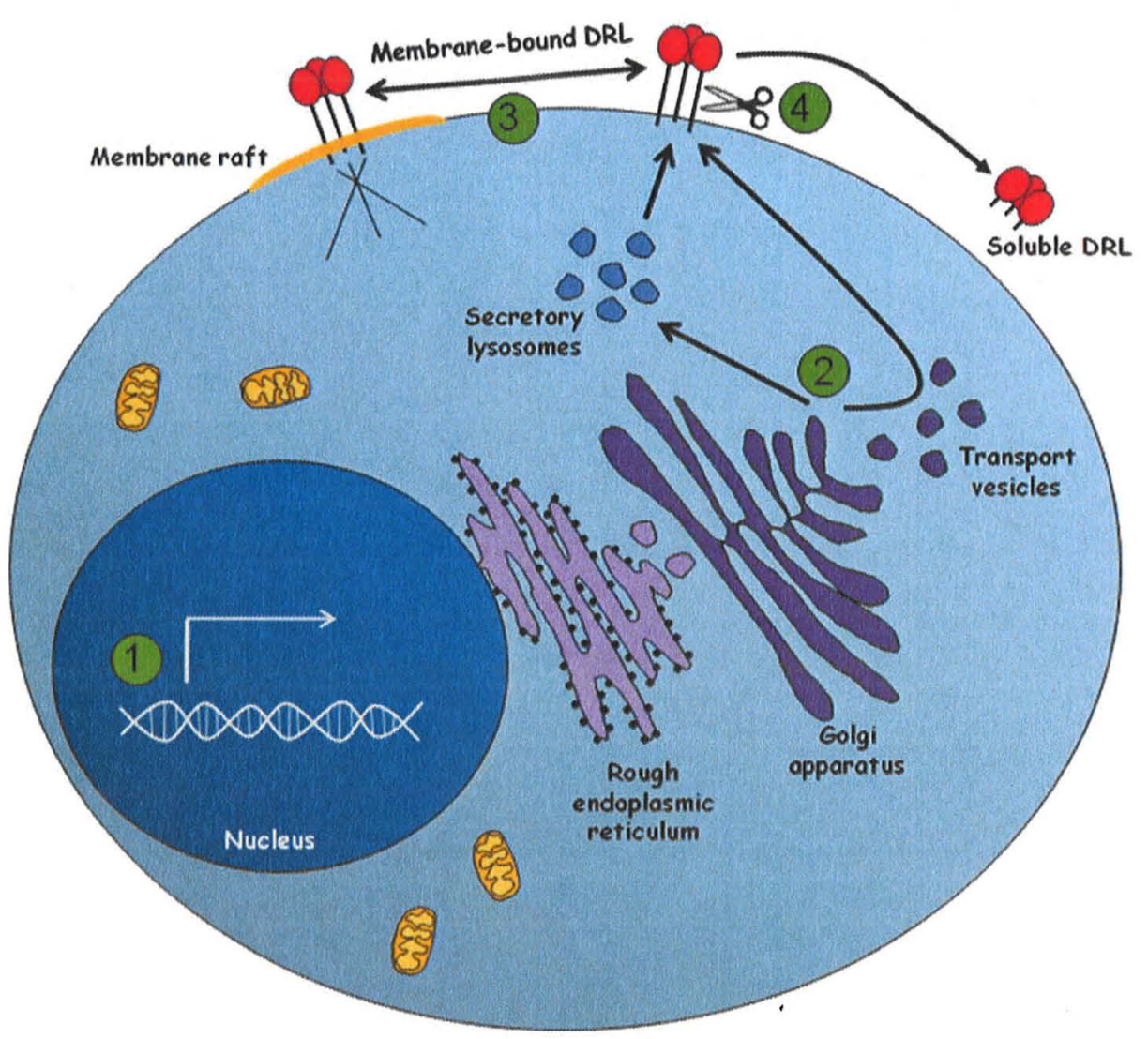

Fig. 1 The expression of death receptor ligands is tightly modulated at different levels. 1 Transcription of death receptor ligands is modulated by groups of transcriptional activators or repressors that are activated and/or de novo expressed in response to a variety of stimuli. 2 FasL is either sorted directly to the plasma membrane or stored in secretory lysosomes. Sorting of FasL is dependent on its cytoplasmic PRD domain, which interacts with proteins that contain SH3 domains or WW motifs, including Nck, Grb2, PSTPIP and members of the PHC family of proteins. Similarly, TNF- $\alpha$, which is normally delivered to the cell surface, can also be stored in secretory lysosomes. However, TNF- $\alpha$ storage depends on a brief exposure at the plasma membrane followed by re-endocytosis. TRAIL can also be found in secretory lysosomes although its sorting mechanism still remains to be elucidated. 3 Recruitment of FasL to membrane rafts

tested [135], and that the TIMP-1-mediated inhibition of TRAIL-induced apoptosis is independent of its ability to inhibit MMPs and ADAMs [134], indicating that MMP and ADAM are not the major players in TRAIL cleavage. In vitro assays indicated that TRAIL shedding can be mediated by cysteine proteases [135], but the identity of the proteases critically involved in TRAIL shedding still remains to be elucidated.

\section{Conclusions and perspectives}

Posttranslational mechanisms involved in modulation of death receptor ligand activity comprise sorting to and boost its killing potential, probably by enhancing the clustering of Fas in target cells. Trafficking of FasL into the rafts is dependent on the cytoplasmic PRD domain of FasL and independent of the SxxS motif. To date, TRAIL and TNF- $\alpha$ redistribution to the membrane rafts is still unclear. 4 Once in the cell surface, death receptor ligands can be proteolytically shed, being converted into soluble molecules. The soluble forms of these ligands can acquire different or even opposing functions, including the induction of proliferation, inflammation and survival. The main enzymes involved in TNF- $\alpha$ and FasL shedding are ADAM-17, ADAM-10, MMP7, and MMP3. TRAIL shedding seems to involve cysteine protease activity, although no specific enzyme has been already described. Regulation of the shedding activity involves a family of proteins called TIMP

storage in different subcellular compartments, including secretory lysosomes and specialized cell membrane microdomains, as well as shedding from the cell membrane by proteolytic activity. These multiple mechanisms are predominant, and of particular relevance, in hematopoietic cells, especially in T lymphocytes and NK cells, where death receptors ligands are used as both death effector and homeostatic mechanisms.

Death receptor ligands were shown to be important to the immune response against tumors and intracellular microorganism-infected cells and to participate in the immune privilege and in the homeostatic control of the immune response, as well as being involved in a diverse array of pathologies, including autoimmune diseases. For 
all these reasons, they have been the subject of much attention aiming to develop novel pharmacological and genetic therapeutic approaches to different diseases.

The systemic administration of recombinant FasL as an antitumor treatment was proved to be unfeasible; even very low doses of this molecule induced massive liver apoptosis, and in many cases resulted in death $[136,137]$. Recently, a FasL-base pro-drug was described as a promising treatment against transformed cells. This pro-drug consists of an engineered inactive form of FasL which is activated by tumor-expressed metalloproteases [138]. One of the major difficulties with this treatment is the proper delivery to tumor cells, which was achieved by addition of a tumor antigen-specific single-chain antibody to the construct. The obvious caveat is that the tumor cell has to express the specific tumor antigen [139]. Also, this technique would be useful not only for FasL but also for TRAIL-based treatments. As the main concern about TRAIL-based therapy is its potential hepatocytotoxicity, a tumor-directed TRAIL may be a safer option for tumor treatment.

Shedding of death receptor ligands from the cell surface, limiting their proapoptotic effect and/or changing their range of action and functions, seems to be another relevant point of therapeutical intervention. Indeed, ADAM17 has been recognized as an important drug target, as TNF- $\alpha$ is involved in a myriad of proinflammatory diseases [140, 141]. Conditional ADAM17-deficient mice are strongly protected against endotoxic shock by reduced TNF- $\alpha$ release [142], and ADAM17 inhibition downmodulates LPS-induced TNF- $\alpha$ secretion, reducing collagenand adjuvant-induced arthritis [143]. Also, inhibitors of TNF- $\alpha$-processing were already shown to ameliorate diverse immunological diseases, like insulin resistance, diabetes, myelodysplastic syndrome, cancer, and sepsis; some of them are already being tested in clinical trials [111, 144-148]. ADAM10 is another interesting therapeutical target due to its FasL sheddase activity. Many tumors express relatively high amounts of the transmembrane form of FasL and use this mechanism as a form of counterattacking the infiltrating T cells [149]. It would be attractive to investigate if ADAM10 is downmodulated in these malignant tissues and if the enforced expression of ADAM10 in these cells would reduce their tumorigenic potential. Another interesting idea would be to enforce the expression of a FasL molecule resistant to ADAM10/MMP7 proteolytic cleavage in transplanted organs. This may mimic immune privileged tissues, where immune responses are abrogated due to the killing of infiltrating cells through a FasL/Fas-dependent mechanism. In this sense, when Langerhans cells were transplanted together with syngeneic FasL-expressing myoblasts they survived longer [150].

Our present state of knowledge of posttranslational modulation of death receptor ligands is summarized in
Fig. 1. Taken together, it is now clear that future studies are needed to improve this knowledge, aiming to devise novel molecular approaches that can be used for clinical applications.

Acknowledgments The work in the Amarante-Mendes laboratory is supported by grants from Fundação de Amparo à Pesquisa do Estado de São Paulo (FAPESP-Brazil), Coordenação de Aperfeiçoamento de Pessoal de Nível Superior (CAPES-Brazil) and the Brazilian Research Council (CNPq-Brazil). The work in the Brunner laboratory is supported by grants from the Swiss National Science Foundation.

\section{References}

1. Ashkenazi A, Dixit VM (1998) Death receptors: signaling and modulation. Science 281:1305-1308

2. Nagata $S$ (1997) Apoptosis by death factor. Cell 88:355-365

3. Gruss HJ, Dower SK (1995) Tumor necrosis factor ligand superfamily: involvement in the pathology of malignant lymphomas. Blood 85:3378-3404

4. Baker SJ, Reddy EP (1998) Modulation of life and death by the TNF receptor superfamily. Oncogene 17:3261-3270

5. Gruss HJ (1996) Molecular, structural, and biological characteristics of the tumor necrosis factor ligand superfamily. Int $J$ Clin Lab Res 26:143-159

6. Schneider P, Holler N, Bodmer JL, Hahne M, Frei K, Fontana A, Tschopp J (1998) Conversion of membrane-bound Fas(CD95) ligand to its soluble form is associated with downregulation of its proapoptotic activity and loss of liver toxicity. J Exp Med 187:1205-1213

7. Bonfoco E, Stuart PM, Brunner T, Lin T, Griffith TS, Gao Y, Nakajima H, Henkart PA, Ferguson TA, Green DR (1998) Inducible nonlymphoid expression of Fas ligand is responsible for superantigen-induced peripheral deletion of T cells. Immunity $9: 711-720$

8. French LE, Hahne M, Viard I, Radlgruber G, Zanone R, Becker K, Muller C, Tschopp $J$ (1996) Fas and Fas ligand in embryos and adult mice: ligand expression in several immune-privileged tissues and coexpression in adult tissues characterized by apoptotic cell turnover. J Cell Biol 133:335-343

9. Brunner T, Yoo NJ, LaFace D, Ware CF, Green DR (1996) Activation-induced cell death in murine $T$ cell hybridomas. Differential regulation of Fas (CD95) versus Fas ligand expression by cyclosporin A and FK506. Int Immunol 8:10171026

10. Hildeman DA, Zhu Y, Mitchell TC, Kappler J, Marrack P (2002) Molecular mechanisms of activated $\mathrm{T}$ cell death in vivo. Curr Opin Immunol 14:354-359

11. Griffith TS, Yu X, Herndon JM, Green DR, Ferguson TA (1996) CD95-induced apoptosis of lymphocytes in an immune privileged site induces immunological tolerance. Immunity 5:7-16

12. Maksimow M, Soderstrom TS, Jalkanen S, Eriksson JE, Hanninen A (2006) Fas costimulation of naive CD4 $T$ cells is controlled by NF-kappaB signaling and caspase activity. J Leukoc Biol 79:369-377

13. Beutler B, Cerami A (1989) The biology of cachectin/TNF: a primary mediator of the host response. Anmu Rev Immunol $7: 625-655$

14. Decker T, Lohmann-Matthes ML, Gifford GE (1987) Cellassociated tumor necrosis factor (TNF) as a killing mechanism of activated cytotoxic macrophages. J Immunol 138:957-962

15. Wiley SR, Schooley K, Smolak PJ, Din WS, Huang CP, Nicholl JK, Sutherland GR, Smith TD, Rauch C, Smith CA, Goodwin 
RG (1995) Identification and characterization of a new member of the TNF family that induces apoptosis. Immunity 3:673-682

16. Zhang C, Zhang J, Niu J, Zhou Z, Zhang J, Tian Z (2008) Interleukin-12 improves cytotoxicity of natural killer cells via upregulated expression of NKG2D. Hum Immunol 69:490-500

17. Kayagaki N, Yamaguchi N, Nakayama M, Takeda K, Akiba H, Tsutsui $\mathrm{H}$, Okamura $\mathrm{H}$, Nakanishi $\mathrm{K}$, Okumura $\mathrm{K}$, Yagita $\mathrm{H}$ (1999) Expression and function of TNF-related apoptosisinducing ligand on murine activated $\mathrm{NK}$ cells. J Immunol 163:1906-1913

18. Kayagaki N, Yamaguchi N, Nakayama M, Eto H, Okumura K, Yagita $H$ (1999) Type I interferons (IFNs) regulate tumor necrosis factor-related apoptosis-inducing ligand (TRAIL) expression on human T cells: a novel mechanism for the antitumor effects of type I IFNs. J Exp Med 189:1451-1460

19. Halaas O, Vik R, Ashkenazi A, Espevik T (2000) Lipopolysaccharide induces expression of APO2 ligand/TRAIL in human monocytes and macrophages. Scand J Immunol 51:244-250

20. Song K, Chen Y, Goke R, Wilmen A, Seidel C, Goke A, Hilliard $B$, Chen $Y(2000)$ Tumor necrosis factor-related apoptosisinducing ligand (TRAIL) is an inhibitor of autoimmune inflammation and cell cycle progression. J Exp Med 191:1095-1104

21. Secchiero P, Zauli G (2008) Tumor-necrosis-factor-related apoptosis-inducing ligand and the regulation of hematopoiesis. Curr Opin Hematol 15:42-48

22. Ishikawa E, Nakazawa M, Yoshinari M, Minami M (2005) Role of tumor necrosis factor-related apoptosis-inducing ligand in immune response to influenza virus infection in mice. $J$ Virol 79:7658-7663

23. Koschny R, Walczak H, Ganten TM (2007) The promise of TRAIL-potential and risks of a novel anticancer therapy. $J$ Mol Med 85:923-935

24. Koschny R, Holland H, Sykora J, Erdal H, Krupp W, Bauer M, Bockmuehl U, Ahnert P, Meixensberger J, Stremmel W, Walczak H, Ganten TM (2009) Bortezomib sensitizes primary human esthesioneuroblastoma cells to TRAIL-induced apoptosis. J Neurooncol, (in press), doi:10.1007/s 1 1060-009-0010-6

25. Syed V, Mukherjee K, Godoy-Tundidor S, Ho SM (2007) Progesterone induces apoptosis in TRAIL-resistant ovarian cancer cells by circumventing c-FLIPL overexpression. J Cell Biochem 102:442-452

26. Walczak H, Miller RE, Ariail K, Gliniak B, Griffith TS, Kubin M, Chin W, Jones J, Woodward A, Le T, Smith C, Smolak P, Goodwin RG, Rauch CT, Schuh JC, Lynch DH (1999) Tumoricidal activity of tumor necrosis factor-related apoptosisinducing ligand in vivo. Nat Med 5:157-163

27. Ganten TM, Koschny R, Sykora J, Schulze-Bergkamen H, Buchler P, Haas TL, Schader MB, Untergasser A, Stremmel W, Walczak $H$ (2006) Preclinical differentiation between apparently safe and potentially hepatotoxic applications of TRAIL either alone or in combination with chemotherapeutic drugs. Clin Cancer Res 12:2640-2646

28. Sah NK, Munshi A, Kurland JF, McDonnell TJ, Su B, Meyn RE (2003) Translation inhibitors sensitize prostate cancer cells to apoptosis induced by tumor necrosis factor-related apoptosisinducing ligand (TRAIL) by activating $\mathrm{c}$-Jun $\mathrm{N}$-terminal kinase. J Biol Chem 278:20593-20602

29. Verbrugge I, de Vries E, Tait SW, Wissink EH, Walczak H, Verheij M, Borst J (2008) lonizing radiation modulates the TRAIL death-inducing signaling complex, allowing bypass of the mitochondrial apoptosis pathway. Oncogene 27:574-584

30. Wissink EH, Verbrugge I, Vink SR, Schader MB, Schaefer U, Walczak $H$, Borst J, Verheij M (2006) TRAIL enhances efficacy of radiotherapy in a p53 mutant, $\mathrm{Bcl}-2$ overexpressing lymphoid malignancy. Radiother Oncol 80:214-222
31. Jo M, Kim TH, Seol DW, Esplen JE, Dorko K, Billiar TR, Strom SC (2000) Apoptosis induced in normal human hepatocytes by tumor necrosis factor-related apoptosis-inducing ligand. Nat Med 6:564-567

32. Zheng SJ, Wang P, Tsabary G, Chen YH (2004) Critical roles of TRAIL in hepatic cell death and hepatic inflammation. J Clin Invest 113:58-64

33. Shudo K, Kinoshita K, Imamura R, Fan H, Hasumoto K, Tanaka M, Nagata S, Suda T (2001) The membrane-bound but not the soluble form of human Fas ligand is responsible for its inflammatory activity. Eur J Immunol 31:2504-2511

34. Suda T, Hashimoto H, Tanaka M, Ochi T, Nagata S (1997) Membrane Fas ligand kills human peripheral blood $T$ lymphocytes, and soluble Fas ligand blocks the killing. J Exp Med 186:2045-2050

35. Brunner T, Wasem C, Torgler R, Cima I, Jakob S, Corazza N (2003) Fas (CD95/Apo-1) ligand regulation in $T$ cell homeostasis, cell-mediated cytotoxicity and immune pathology. Semin Immunol 15:167-176

36. Kavurma MM, Bennett MR (2008) Expression, regulation and function of trail in atherosclerosis. Biochem Pharmacol $75: 1441-1450$

37. Kavurma MM, Khachigian LM (2003) Signaling and transcriptional control of Fas ligand gene expression. Cell Death Differ 10:36-44

38. Liu H, Sidiropoulos P, Song G, Pagliari LJ, Birrer MJ, Stein B, Anrather J, Pope RM (2000) TNF-alpha gene expression in macrophages: regulation by NF-kappa B is independent of c-Jun or C/EBP beta. J Immunol 164:4277-4285

39. Griffith TS, Brunner T, Fletcher SM, Green DR, Ferguson TA (1995) Fas ligand-induced apoptosis as a mechanism of immune privilege. Science 270:1189-1192

40. Kauma SW, Huff TF, Hayes N, Nilkaeo A (1999) Placental Fas ligand expression is a mechanism for maternal immune tolerance to the fetus. J Clin Endocrinol Metab 84:2188-2194

41. O'Connell J, Bennett MW, O'Sullivan GC, O'Callaghan J Collins JK, Shanahan F (1999) Expression of Fas (CD95/APO1) ligand by human breast cancers: significance for tumor immune privilege. Clin Diagn Lab Immunol 6:457-463

42. O'Connell J, O'Sullivan GC, Collins JK, Shanahan F (1996) The Fas counterattack: Fas-mediated $T$ cell killing by colon cancer cells expressing Fas ligand. J Exp Med 184:1075-1082

43. Xerri L, Devilard E, Hassoun J, Mawas C, Birg F (1997) Fas ligand is not only expressed in immune privileged human organs but is also coexpressed with Fas in various epithelial tissues. Mol Pathol 50:87-91

44. Blott EJ, Bossi G, Clark R, Zvelebil M, Griffiths GM (2001) Fas ligand is targeted to secretory lysosomes via a proline-rich domain in its cytoplasmic tail. J Cell Sci 114:2405-2416

45. Bossi G, Griffiths GM (1999) Degranulation plays an essential part in regulating cell surface expression of Fas ligand in $\mathrm{T}$ cells and natural killer cells. Nat Med 5:90-96

46. Qian J, Chen W, Lettau M, Podda G, Zornig M, Kabelitz D, Janssen $O$ (2006) Regulation of FasL expression: a SH3 domain containing protein family involved in the lysosomal association of FasL. Cell Signal 18:1327-1337

47. Montel AH, Bochan MR, Hobbs JA, Lynch DH, Brahmi Z (1995) Fas involvement in cytotoxicity mediated by human NK cells. Cell Immunol 166:236-246

48. Suda T, Okazaki T, Naito Y, Yokota T, Arai N, Ozaki S, Nakao K, Nagata $S$ (1995) Expression of the Fas ligand in cells of $T$ cell lineage. J Immunol 154:3806-3813

49. He JS, Ostergaard HL (2007) CTLs contain and use intracellular stores of FasL distinct from cytolytic granules. J Immunol 179:2339-2348 
50. Hanna WL, Turbov JM, Jackman HL, Tan F, Froelich CJ (1994) Dominant chymotrypsin-like esterase activity in human lymphocyte granules is mediated by the serine carboxypeptidase called cathepsin A-like protective protein. J Immunol 153:46634672

51. Lettau M, Schmidt H, Kabelitz D, Janssen O (2007) Secretory lysosomes and their cargo in $\mathrm{T}$ and NK cells. Immunol Lett 108:10-19

52. Jenne DE, Tschopp J (1988) Granzymes, a family of serine proteases released from granules of cytolytic $\mathrm{T}$ lymphocytes upon $T$ cell receptor stimulation. Immunol Rev 103:53-71

53. Peters PJ, Borst J, Oorschot V, Fukuda M, Krahenbuhl O, Tschopp J, Slot JW, Geuze HJ (1991) Cytotoxic T lymphocyte granules are secretory lysosomes, containing both perforin and granzymes. J Exp Med 173:1099-1109

54. Puri N, Roche PA (2008) Mast cells possess distinct secretory granule subsets whose exocytosis is regulated by different SNARE isoforms. Proc Natl Acad Sci USA 105:2580-2585

55. Bossi G, Griffiths GM (2005) CTL secretory lysosomes: biogenesis and secretion of a harmful organelle. Semin Immunol $17: 87-94$

56. Kojima Y, Kawasaki-Koyanagi A, Sueyoshi N, Kanai A, Yagita $\mathrm{H}$, Okumura $\mathrm{K}(2002)$ Localization of Fas ligand in cytoplasmic granules of CD8 + cytotoxic $T$ lymphocytes and natural killer cells: participation of Fas ligand in granule exocytosis model of cytotoxicity. Biochem Biophys Res Commun 296:328-336

57. Kassahn D, Nachbur U, Conus S, Micheau O, Schneider P, Simon HU, Brunner T (2009) Distinct requirements for activation-induced cell surface expression of preformed Fas/CD95 ligand and cytolytic granule markers in $T$ cells. Cell Death Differ 16:115-124

58. Schmidt H, Gelhaus C, Lucius R, Nebendahl M, Leippe M, Janssen $O$ (2009) Enrichment and analysis of secretory lysosomes from lymphocyte populations. BMC Immunol 10:41

59. Pond L, Kuhn LA, Teyton L, Schutze MP, Tainer JA, Jackson MR, Peterson PA (1995) A role for acidic residues in di-leucine motif-based targeting to the endocytic pathway. J Biol Chem 270:19989-19997

60. Trowbridge IS, Collawn JF, Hopkins CR (1993) Signal-dependent membrane protein trafficking in the endocytic pathway. Annu Rev Cell Biol 9:129-161

61. Nachbur U, Kassahn D, Yousefi S, Legler DF, Brunner T (2006) Posttranscriptional regulation of Fas (CD95) ligand killing activity by lipid rafts. Blood 107:2790-2796

62. Linkermann A, Gelhaus C, Lettau M, Qian J, Kabelitz D, Janssen $O(2009)$ Identification of interaction partners for individual SH3 domains of Fas ligand associated members of the $\mathrm{PCH}$ protein family in T lymphocytes. Biochim Biophys Acta 1794:168-176

63. Voss M, Lettau M, Janssen O (2009) Identification of SH3 domain interaction partners of human FasL (CD178) by phage display screening. BMC Immunol 10:53

64. Wenzel J, Sanzenbacher R, Ghadimi M, Lewitzky M, Zhou Q, Kaplan DR, Kabelitz D, Feller SM, Janssen O (2001) Multiple interactions of the cytosolic polyproline region of the CD95 ligand: hints for the reverse signal transduction capacity of a death factor. FEBS Lett 509:255-262

65. Ghadimi MP, Sanzenbacher R, Thiede B, Wenzel J, Jing Q, Plomann M, Borkhardt A, Kabelitz D, Janssen O (2002) Identification of interaction partners of the cytosolic polyproline region of CD95 ligand (CD178). FEBS Lett 519:50-58

66. Hane M, Lowin B, Peitsch M, Becker K, Tschopp J (1995) Interaction of peptides derived from the Fas ligand with the Fyn-SH3 domain. FEBS Lett 373:265-268

67. Lettau M, Qian J, Linkermann A, Latreille M, Larose L, Kabelitz D, Janssen O (2006) The adaptor protein Nck interacts with Fas ligand: Guiding the death factor to the cytotoxic immunological synapse. Proc Natl Acad Sci USA 103:5911-5916

68. Baum W, Kirkin V, Fernandez SB, Pick R, Lettau M, Janssen O, Zornig M (2005) Binding of the intracellular Fas ligand (FasL) domain to the adaptor protein PSTPIP results in a cytoplasmic localization of FasL. J Biol Chem 280:40012-40024

69. Zuccato E, Blott EJ, Holt O, Sigismund S, Shaw M, Bossi G, Griffiths GM (2007) Sorting of Fas ligand to secretory lysosomes is regulated by mono-ubiquitylation and phosphorylation. J Cell Sci 120:191-199

70. Thornhill PB, Cohn JB, Stanford WL, Desbarats J (2008) The adaptor protein Grb2 regulates cell surface Fas ligand in Schwann cells. Biochem Biophys Res Commun 376:341-346

71. Olszewski MB, Groot AJ, Dastych J, Knol EF (2007) TNF trafficking to human mast cell granules: mature chain-dependent endocytosis. J Immunol 178:5701-5709

72. Olszewski MB, Trzaska D, Knol EF, Adamczewska V, Dastych J (2006) Efficient sorting of TNF-alpha to rodent mast cell granules is dependent on $\mathrm{N}$-linked glycosylation. Eur J Immunol 36:997-1008

73. Beil WJ, Login GR, Aoki M, Lunardi LO, Morgan ES, Galli SJ, Dvorak AM (1996) Tumor necrosis factor alpha immunoreactivity of rat peritoneal mast cell granules decreases during early secretion induced by compound 48/80: an ultrastructural immunogold morphometric analysis. Int Arch Allergy Immunol 109:383-389

74. Walsh LJ, Trinchieri G, Waldorf HA, Whitaker D, Murphy GF (1991) Human dermal mast cells contain and release tumor necrosis factor alpha, which induces endothelial leukocyte adhesion molecule 1. Proc Natl Acad Sci USA 88:4220-4224

75. Shurety W, Merino-Trigo A, Brown D, Hume DA, Stow JL (2000) Localization and post-Golgi trafficking of tumor necrosis factoralpha in macrophages. J Interferon Cytokine Res 20:427-438

76. Cassatella MA, Huber V, Calzetti F, Margotto D, Tamassia N, Peri G, Mantovani A, Rivoltini L, Tecchio C (2006) Interferonactivated neutrophils store a TNF-related apoptosis-inducing ligand (TRAIL/Apo-2 ligand) intracellular pool that is readily mobilizable following exposure to proinflammatory mediators. J Leukoc Biol 79:123-132

77. Kemp TJ, Ludwig AT, Earel JK, Moore JM, Vanoosten RL, Moses B, Leidal K, Nauseef WM, Griffith TS (2005) Neutrophil stimulation with Mycobacterium bovis bacillus Calmette-Guerin (BCG) results in the release of functional soluble TRAIL/ Apo-2L. Blood 106:3474-3482

78. Monleon I, Martinez-Lorenzo MJ, Monteagudo L, Lasierra P, Taules M, Iturralde M, Pineiro A, Larrad L, Alava MA, Naval J, Anel A (2001) Differential secretion of Fas ligand- or APO2 ligand/TNF-related apoptosis-inducing ligand-carrying microvesicles during activation-induced death of human $\mathrm{T}$ cells. J Immunol 167:6736-6744

79. Simons MP, Leidal KG, Nauseef WM, Griffith TS (2008) TNF-related apoptosis-inducing ligand (TRAIL) is expressed throughout myeloid development, resulting in a broad distribution among neutrophil granules. J Leukoc Biol 83:621-629

80. Simons MP, Moore JM, Kemp TJ, Griffith TS (2007) Identification of the mycobacterial subcomponents involved in the release of tumor necrosis factor-related apoptosis-inducing ligand from human neutrophils. Infect Immun 75:1265-1271

81. Simons K, lkonen E (1997) Functional rafts in cell membranes. Nature 387:569-572

82. Shogomori H, Brown DA (2003) Use of detergents to study membrane rafts: the good, the bad, and the ugly. Biol Chem 384:1259-1263

83. Dykstra M, Cherukuri A, Sohn HW, Tzeng SJ, Pierce SK (2003) Location is everything: lipid rafts and immune cell signaling. Annu Rev Immunol 21:457-481 
84. Doan JE, Windmiller DA, Riches DW (2004) Differential regulation of TNF-R1 signaling: lipid raft dependency of $\mathrm{p} 42 \mathrm{mapk}$ erk2 activation, but not NF-kappaB activation. I Immuno 172:7654-7660

85. Legler DF, Micheau O, Doucey MA, Tschopp J, Bron C (2003) Recruitment of TNF receptor 1 to lipid rafts is essential for TNFalpha-mediated NF-kappaB activation. Immunity 18:655664

86. Cahuzac N, Baum W, Kirkin V, Conchonaud F, Wawrezinieck L, Marguet D, Janssen O, Zornig M, Hueber AO (2006) Fas ligand is localized to membrane rafts, where it displays increased cell death-inducing activity. Blood 107:2384-2391

87. Henkler F, Behrle E, Dennehy KM, Wicovsky A, Peters N Warnke C, Pfizenmaier K, Wajant $\mathrm{H}$ (2005) The extracellular domains of FasL and Fas are sufficient for the formation of supramolecular FasL-Fas clusters of high stability. J Cell Biol 168:1087-1098

88. Gajate C, Mollinedo F (2005) Cytoskeleton-mediated death receptor and ligand concentration in lipid rafts forms apoptosispromoting clusters in cancer chemotherapy. J Biol Chem 280:11641-11647

89. Holler N, Tardivel A, Kovacsovics-Bankowski M, Hertig S, Gaide O, Martinon F, Tinel A, Deperthes D, Calderara S, Schulthess T, Engel J, Schneider P, Tschopp J (2003) Two adjacent trimeric Fas ligands are required for Fas signaling and formation of a death-inducing signaling complex. Mol Cell Biol 23:1428-1440

90. Eramo A, Sargiacomo M, Ricci-Vitiani L, Todaro M, Stassi G, Messina CG, Parolini I, Lotti F, Sette G, Peschle C, De Maria R (2004) CD95 death-inducing signaling complex formation and internalization occur in lipid rafts of type 1 and type II cells. Eur J Immunol 34:1930-1940

91. Legembre P, Daburon S, Moreau P, Moreau JF, Taupin JL (2006) Modulation of Fas-mediated apoptosis by lipid rafts in $\mathrm{T}$ lymphocytes. J Immunol 176:716-720

92. Muppidi JR, Siegel RM (2004) Ligand-independent redistribution of Fas (CD95) into lipid rafts mediates clonotypic $\mathrm{T}$ cell death. Nat Immunol 5:182-189

93. Treede I, Braun A, Jeliaskova P, Giese T, Fullekrug J, Griffiths G, Stremmel W, Ehehalt R (2009) TNF-alpha-induced up-regulation of pro-inflammatory cytokines is reduced by phosphatidylcholine in intestinal epithelial cells. BMC Gastroenterol 9:53

94. Rossin A, Derouet M, Abdel-Sater F, Hueber AO (2009) Palmitoylation of the TRAIL receptor DR4 confers an efficient TRAIL-induced cell death signalling. Biochem J 419: 185-92, (2 p following 192)

95. Chakrabandhu K, Herines Z, Huault S, Dost B, Peng L, Conchonaud F, Marguet D, He HT, Hueber AO (2007) Palmitoylation is required for efficient Fas cell death signaling. EMBO J 26:209-220

96. Higuchi $H$, Yamashita T, Yoshikawa H, Tohyama M (2003) PKA phosphorylates the $\mathrm{p} 75$ receptor and regulates its localization to lipid rafts. EMBO J 22:1790-1800

97. Neumann-Giesen C, Falkenbach B, Beicht P, Claasen S, Luers G, Stuermer CA, Herzog V, Tikkanen R (2004) Membrane and raft association of reggie-1/flotillin-2: role of myristoylation, palmitoylation and oligomerization and induction of flopodia by overexpression. Biochem $\mathrm{J}$ 378:509-518

98. Tanaka M, Itai T, Adachi M, Nagata S (1998) Downregulation of Fas ligand by shedding. Nat Med 4:31-36

99. Matute-Bello G, Winn RK, Jonas M, Chi EY, Martin TR, Liles WC (2001) Fas (CD95) induces alveolar epithelial cell apoptosis in vivo: implications for acute pulmonary inflammation. Am J Pathol 158:153-161
100. Serrao KL, Fortenberry JD, Owens ML, Harris FL, Brown LA (2001) Neutrophils induce apoptosis of lung epithelial cells via release of soluble Fas ligand. Am J Physiol Lung Cell Mo Physiol 280:L298-L305

101. Song E, Chen J, Ouyang N, Su F, Wang M, Heemann U (2001) Soluble Fas ligand released by colon adenocarcinoma cells induces host lymphocyte apoptosis: an active mode of immune evasion in colon cancer. Br J Cancer 85:1047-1054

102. O'Reilly LA, Tai L, Lee L, Kruse EA, Grabow S, Fairlie WD Haynes NM, Tarlinton DM, Zhang JG, Belz GT, Smyth MJ Bouillet P, Robb L, Strasser A (2009) Membrane-bound Fas ligand only is essential for Fas-induced apoptosis. Nature 461:659-663

103. Schulte M, Reiss K, Lettau M, Maretzky T, Ludwig A Hartmann D, de Strooper B, Janssen O, Saftig P (2007) ADAM10 regulates FasL cell surface expression and modulates FasL-induced cytotoxicity and activation-induced cell death. Cell Death Differ 14:1040-1049

104. Knox PG, Milner AE, Green NK, Eliopoulos AG, Young LS (2003) Inhibition of metalloproteinase cleavage enhances the cytotoxicity of Fas ligand. J Immunol 170:677-685

105. Kriegler M, Perez C, DeFay K, Albert I, Lu SD (1988) A novel form of TNF/cachectin is a cell surface cytotoxic transmembrane protein: ramifications for the complex physiology of TNF. Cell 53:45-53

106. Perez C, Albert I, DeFay K, Zachariades N, Gooding L, Kriegler $M$ (1990) A nonsecretable cell surface mutant of tumor necrosis factor (TNF) kills by cell-to-cell contact. Cell 63:251-258

107. Borsotti C, Franklin AR, Lu SX, Kim TD, Smith OM, Suh D, King CG, Chow A, Liu C, Alpdogan O, van den Brink MR (2007) Absence of donor T-cell-derived soluble TNF decreases graft-versus-host disease without impairing graft-versus-tumor activity, Blood 110:783-786

108. Muller S, Rihs S, Dayer Schneider JM, Paredes BE, Seibold I, Brunner T, Mueller C (2009) Soluble TNF-alpha but not transmembrane TNF-alpha sensitizes $\mathrm{T}$ cells for enhanced activation-induced cell death. Eur J Immunol 39:3171-3180. doi:10.1002/eji.200939554

109. Vassalli P (1992) The pathophysiology of tumor necrosis factors. Annu Rev Immunol 10:411-452

110. Mueller C, Corazza N, Trachsel-Loseth S, Eugster HP, BuhlerJungo M, Brunner T, Imboden MA (1999) Noncleavable transmembrane mouse tumor necrosis factor-alpha (TNFalpha) mediates effects distinct from those of wild-type TNFalpha in vitro and in vivo. $\mathrm{J}$ Biol Chem 274:38112-38118

111. Mohler KM, Sleath PR, Fitzner JN, Cerretti DP, Alderson M Kerwar SS, Torrance DS, Otten-Evans C, Greenstreet $T$, Weerawarna $K$, Kronheim SR, Petersen M, Gerhart $M$, Koslosky CJ, March CJ, Black RA (1994) Protection against a lethal dose of endotoxin by an inhibitor of tumour necrosis factor processing. Nature 370:218-220

112. Black RA, Rauch CT, Kozlosky CJ, Peschon JJ, Slack JL Wolfson MF, Castner BJ, Stocking KL, Reddy P, Srinivasan S, Nelson N, Boiani N, Schooley KA, Gerhart M, Davis R, Fitzner JN, Johnson RS, Paxton RJ, March CJ, Cerretti DP (1997) A metalloproteinase disintegrin that releases tumour-necrosis factor-alpha from cells. Nature 385:729-733

113. Reddy P, Slack JL, Davis R, Cerretti DP, Kozlosky CJ, Blanton RA, Shows D, Peschon JJ, Black RA (2000) Functional analysis of the domain structure of tumor necrosis factor-alpha converting enzyme. J Biol Chem 275:14608-14614

114. Itai T, Tanaka $M$, Nagata $S$ (2001) Processing of tumor necrosis factor by the membrane-bound TNF-alpha-converting enzyme, but not its truncated soluble form. Eur J Biochem 268:2074 2082 
115. Zheng Y, Saftig P, Hartmann D, Blobel C (2004) Evaluation of the contribution of different ADAMs to tumor necrosis factor alpha (TNFalpha) shedding and of the function of the TNFalpha ectodomain in ensuring selective stimulated shedding by the TNFalpha convertase (TACE/ADAM17). J Biol Chem 279:42898-42906

116. Condon TP, Flournoy S, Sawyer GJ, Baker BF, Kishimoto TK, Bennett CF (2001) ADAM17 but not ADAM10 mediates tumor necrosis factor-alpha and L-selectin shedding from leukocyte membranes. Antisense Nucleic Acid Drug Dev 11:107-116

117. Lunn CA, Fan X, Dalie B, Miller K, Zavodny PJ, Narula SK, Lundell D (1997) Purification of ADAM 10 from bovine spleen as a TNFalpha convertase. FEBS Lett 400:333-335

118. Rosendahl MS, Ko SC, Long DL, Brewer MT, Rosenzweig B, Hedl E, Anderson L, Pyle SM, Moreland J, Meyers MA, Kohno $T$, Lyons D, Lichenstein HS (1997) Identification and characterization of a pro-tumor necrosis factor-alpha-processing enzyme from the ADAM family of zinc metalloproteases. J Biol Chem 272:24588-24593

119. Mezyk-Kopec R, Bzowska M, Stalinska K, Chelmicki T, Podkalicki M, Jucha J, Kowalczyk K, Mak P, Bereta J (2009) Identification of ADAM10 as a major TNF sheddase in ADAM17-deficient fibroblasts. Cytokine 46:309-315

120. Le Gall SM, Bobe P, Reiss K, Horiuchi K, Niu XD, Lundell D, Gibb DR, Conrad D, Saftig P, Blobel CP (2009) ADAMs 10 and 17 represent differentially regulated components of a general shedding machinery for membrane proteins such as transforming growth factor alpha, L-selectin, and tumor necrosis factor alpha. Mol Biol Cell 20:1785-1794

121. Hartmann D, de Strooper B, Serneels L, Craessaerts K, Herreman A, Annaert W, Umans L, Lubke T, Lena Illert A, von Figura K, Saftig P (2002) The disintegrin/metalloprotease ADAM 10 is essential for Notch signalling but not for alpha-secretase activity in fibroblasts. Hum Mol Genet 11:26152624

122. Mitsiades N, Yu WH, Poulaki V, Tsokos M, Stamenkovic I (2001) Matrix metalloproteinase-7-mediated cleavage of Fas ligand protects tumor cells from chemotherapeutic drug cytotoxicity. Cancer Res 61:577-581

123. Powell WC, Fingleton B, Wilson CL, Boothby M, Matrisian LM (1999) The metalloproteinase matrilysin proteolytically generates active soluble Fas ligand and potentiates epithelial cell apoptosis. Curr Biol 9:1441-1447

124. Matsuno $\mathrm{H}$, Yudoh $\mathrm{K}$, Watanabe $\mathrm{Y}$, Nakazawa $\mathrm{F}$, Aono $\mathrm{H}$, Kimura T (2001) Stromelysin-1 (MMP-3) in synovial fluid of patients with rheumatoid arthritis has potential to cleave membrane bound Fas ligand. J Rheumatol 28:22-28

125. Horiuchi K, Le Gall S, Schulte M, Yamaguchi T, Reiss K, Murphy G, Toyama Y, Hartmann D, Saftig P, Blobel CP (2007) Substrate selectivity of epidermal growth factor-receptor ligand sheddases and their regulation by phorbol esters and calcium influx. Mol Biol Cell 18:176-188

126. Stetler-Stevenson WG (2008) Tissue inhibitors of metalloproteinases in cell signaling: metalloproteinase-independent biological activities. Sci Signal 1:re6

127. Amour A, Slocombe PM, Webster A, Butler M, Knight CG, Smith BJ, Stephens PE, Shelley C, Hutton M, Knauper V, Docherty AJ, Murphy G (1998) TNF-alpha converting enzyme (TACE) is inhibited by TIMP-3. FEBS Lett $435: 39-44$

128. Lee MH, Rapti M, Murphy G (2005) Total conversion of tissue inhibitor of metalloproteinase (TIMP) for specific metalloproteinase targeting: fine-tuning TIMP-4 for optimal inhibition of tumor necrosis factor-\{alpha\}-converting enzyme. J Biol Chem 280:15967-15975

129. Ahonen M, Poukkula M, Baker AH, Kashiwagi M, Nagase H, Eriksson JE, Kahari VM (2003) Tissue inhibitor of metalloproteinases- 3 induces apoptosis in melanoma cells by stabilization of death receptors. Oncogene 22:2121-2134

130. Baker AH, Zaltsman AB, George SJ, Newby AC (1998) Divergent effects of tissue inhibitor of metalloproteinase-1, -2 , or -3 overexpression on rat vascular smooth muscle cell invasion, proliferation, and death in vitro. TIMP-3 promotes apoptosis. J Clin Invest 101:1478-1487

131. Bond M, Murphy G, Bennett MR, Amour A, Knauper V, Newby $\mathrm{AC}, \mathrm{Baker} \mathrm{AH}(2000)$ Localization of the death domain of tissue inhibitor of metalloproteinase- 3 to the $\mathrm{N}$ terminus. Metalloproteinase inhibition is associated with proapoptotic activity. J Biol Chem 275:41358-41363

132. Li G, Fridman R, Kim HR (1999) Tissue inhibitor of metalloproteinase-1 inhibits apoptosis of human breast epithelial cells. Cancer Res 59:6267-6275

133. Chesler L, Golde DW, Bersch N, Johnson MD (1995) Metalloproteinase inhibition and erythroid potentiation are independent activities of tissue inhibitor of metalloproteinases1. Blood 86:4506-4515

134. Liu XW, Taube ME, Jung KK, Dong Z, Lee YJ, Roshy S, Sloane BF, Fridman R, Kim HR (2005) Tissue inhibitor of metalloproteinase-1 protects human breast epithelial cells from extrinsic cell death: a potential oncogenic activity of tissue inhibitor of metalloproteinase-1. Cancer Res 65:898-906

135. Mariani SM, Krammer PH (1998) Differential regulation of TRAIL and CD95 ligand in transformed cells of the T and B lymphocyte lineage. Eur J Immunol 28:973-982

136. Loo G, Lippens S, Hahne M, Matthijssens F, Declercq W, Saelens X, Vandenabeele P (2003) A Bcl-2 transgene expressed in hepatocytes does not protect mice from fulminant liver destruction induced by Fas ligand. Cytokine 22:62-70

137. Ogasawara J, Watanabe-Fukunaga R, Adachi M, Matsuzawa A, Kasugai T, Kitamura Y, Itoh N, Suda T, Nagata S (1993) Lethal effect of the anti-Fas antibody in mice. Nature 364:806-809

138. Watermann I, Gerspach J, Lehne M, Seufert J, Schneider B, Pfizenmaier K, Wajant $\mathrm{H}$ (2007) Activation of CD95L fusion protein prodrugs by tumor-associated proteases. Cell Death Differ 14:765-774

139. Kassahn D, Nachbur U, Brunner T (2007) CD95L pro-drug: a novel Swiss Army Knife in cancer therapy? Cell Death Differ 14:393-394

140. Moss ML, White JM, Lambert MH, Andrews RC (2001) TACE and other ADAM proteases as targets for drug discovery. Drug Discov Today 6:417-426

141. Glunde K, Stasinopoulos I (2009) ADAM17: the new face of breast cancer-promoting metalloprotease activity. Cancer Biol Ther 8:1055-1057

142. Horiuchi K, Kimura T, Miyamoto T, Takaishi H, Okada $Y$, Toyama Y, Blobel CP (2007) Cutting edge: TNF-alphaconverting enzyme (TACE/ADAM17) inactivation in mouse myeloid cells prevents lethality from endotoxin shock. J Immunol 179:2686-2689

143. Zhang $Y$, Hegen $M, X u$ J, Keith JC Jr, Jin G, Du X, Cummons T, Sheppard BJ, Sun L, Zhu Y, Rao VR, Wang Q, Xu W, Cowling R, Nickerson-Nutter CL, Gibbons J, Skotnicki J, Lin LL, Levin J (2004) Characterization of (2R, 3S)-2-(I[4-(2-butynyloxy) phenyl]sulfonyl]amino)- $N$, 3-dihydroxybutanamide, a potent and selective inhibitor of TNF-alpha converting enzyme. Int Immunopharmacol 4:1845-1857

144. Arimura K, Arima N, Matsushita K, Ohtsubo H, Fujiwara H, Kukita T, Ozaki A, Hagiwara T, Hamada H, Yoshino K, Tei C (2004) Matrix metalloproteinase inhibitor reduces apoptosis induction of bone marrow cells in MDS-RA. Eur $J$ Haematol 73:17-24

145. DiMartino M, Wolff C, High W, Stroup G, Hoffman S, Laydon J, Lee JC, Bertolini D, Galloway WA, Crimmin MJ, Davis M, 
Davies S (1997) Anti-arthritic activity of hydroxamic acid-based pseudopeptide inhibitors of matrix metalloproteinases and TNF alpha processing. Inffamm Res 46:211-215

146. Drummond AH, Beckett P, Brown PD, Bone EA, Davidson AH, Galloway WA, Gearing AJ, Huxley P, Laber D, McCourt M, Whittaker M, Wood LM, Wright A (1999) Preclinical and clinical studies of MMP inhibitors in cancer. Ann N Y Acad Sci 878:228-235

147. Morimoto Y, Nishikawa K, Ohashi M (1997) KB-R7785, a novel matrix metalloproteinase inhibitor, exerts its antidiabetic effect by inhibiting tumor necrosis factor-alpha production. Life Sci 61:795-803

148. Togashi N, Ura N, Higashiura K, Murakami H, Shimamoto K (2002) Effect of TNF-alpha-converting enzyme inhibitor on insulin resistance in fructose-fed rats. Hypertension 39:578-580

149. Igney FH, Krammer PH (2005) Tumor counterattack: fact or fiction? Cancer Immunol Immunother 54:1127-1136

150. Lau HT, Yu M, Fontana A, Stoeckert CJ Jr (1996) Prevention of islet allograft rejection with engineered myoblasts expressing FasL in mice. Science 273:109-112 